\title{
HUBUNGAN PEMAKAIAN DIAPERS DENGAN KEJADIAN RUAM POPOK PADA BAYI USIA 6 - 12 BULAN
}

\author{
Siti Aisyah* \\ *Dosen Program Studi Diploma III Kebidanan Universitas Islam Lamongan \\ J1 Veteran No 53 A Lamongan
}

\begin{abstract}
ABSTRAKS
Diapers merupakan alat yang berupa popok sekali pakai berdaya serap tinggi yang terbuat dari plastik dan campuran bahan kimia untuk menampung sisa-sisa metabolisme seperti air seni dan feses. Kulit bayi biasanya masih sangat halus serta masih sangat sensitif bila dipakai produk-produk bayi yang beredar di pasaran. Kadang dengan kesensitifan kulit bayi seringkali bayi mengalami berbagai macam penyakit. Gangguan kulit yang sering terjadi pada bayi adalah biang keringat, iritasi, ruam popok ataupun eksim popok. Dari survey awal yang dilakukan pada bulan februari 2015 di polindes putat kumpul pada 7 bayi, didapatkan 4 bayi yang memakai diapers dan mengalami ruam popok $(57,14 \%)$ dan 3 bayi ( $42,86 \%$ ) tidak mengalami ruam popok.

Desain penelitian ini adalah penelitian studi korelasional dengan menggunakan cross sectional. Besar sampel 30 bayi pada bayi usia 6 bulan -12 bulan dengan menggunakan teknik simple random sampling. Cara pengumpulan data dengan menggunakan lembar kuesioner dan observasi. Data yang terkumpul dianalisis dengan menggunakan uji koefisien kontingensi dengan tingkat kemaknaan $\alpha=0,05$

Hasil penelitian menunjukkan bahwa dari 30 responden didapatkan 17 responden $(56,67 \%)$ sering pakai diapers dan 10 responden ( $33,33 \%)$ yang jarang pakai diapers, serta 3 responden ( $10 \%$ ) yang tidak pakai diapers Sedangkan yang 20 responden $(66,67 \%)$ terjadi ruam popok dan 10 responden $(33,33 \%)$ tidak terjadi ruam popok. Setelah dillakukan uji koefisien kontingensi ternyata hasilnya $0,004<0,05$ maka $\mathrm{H}_{0}$ ditolak.

Disimpulkan bahwa ada hubungan pemakaian diapers dengan kejadian ruam popok pada bayi usia 6 bulan - 1 tahun. Pemakaian diapers yang terlalu sering akan menyebabkan ruam popok karena akan menimbulkan berkembang biakan mikro organisme semakin banyak sehingga bidan setempat harus melakukan penyuluhan tentang pemakaian diapers.
\end{abstract}

\section{Kata Kunci : Pemakaian diapers, Ruam popok.}

\section{PENDAHULUAN}

\subsection{Latar Belakang}

Diapers merupakan alat yang berupa popok sekali pakai berdaya serap tinggi yang terbuat dari plastik dan campuran bahan kimia untuk menampung sisa-sisa metabolisme seperti air seni dan feses. Di era modern saat ini, Segala Sesuatu dibuat canggih dengan tujuan memberikan kemudahan kepada masyarakat. Khusus bagi para ibu yang memiliki bayi dan balita kini sudah banyak produk popok bayi sekali pakai yang praktis, Sehingga para ibu tidak direpotkan dengan 
banyak cucian, Walaupun kita dimudahkan dengan segala sesuatunya saat buah hati kita (Kebiasaan) memakai diapres dengan alasan praktis dan ekonomis. Kulit bayi biasanya masih sangat halus serta masih sangat sensitif bila dipakai produk-produk bayi yang beredar di pasaran. Kadang dengan kesensitifan kulit bayi seringkali bayi mengalami berbagai macam penyakit. Gangguan kulit yang sering terjadi pada bayi adalah biang keringat, iritasi, ruam popok ataupun eksim popok (Diena, 2009).

Di Indonesia terdapat bayi disertai kulit yang keras bersisik, berbintil, bahkan melepuh dan lecet, yang menimbulkan gatal dan perih pada bayi, kurang lebih $50 \%$ bayi dan anak yang memakai popok pernah mengalaminya. Penyakit ini juga mengenai $7-35 \%$ dari populasi bayi. (Lestari, 2003). Penelitian di Inggris menemukan, 25 persen dari 12.000 bayi berusia empat minggu mengalami ruam popok. Gangguan kulit ini menyerang bagian tubuh bayi yang tertutup popok. Daerah yang terserang biasanya area genital, lipatan paha dan bokong. Kulit anak cenderung terlihat merah dan agak bersisik. Salah satu upaya yang dapat dilakukan untuk mencegah terjadinya ruam popok

Menurut laporan Journal of Pediatrics terdapat 54\% bayi berumur 1 bulan yang mengalami ruam popok setelah memakai disposable diaper. Dalam artikel yang berjudul Disposable Diapers : Potential Health Hazards, Cathy Allison menyatakan kalau Procter \& Gamble (produsen Pampers dan Huggies) melalui penelitiannya memperoleh data mencengangkan. Angka ruam popok pada bayi yang menggunakan disposable diaper meningkat dari $7,1 \%$ hingga $61 \%$. Sementara itu Mark Fearer dalam artikelnya yang berjudul Diaper Debate-Not Over Yet menyatakan beberapa hasil studi medis menunjukkan angka peningkatan ruam popok $7 \%$ pada tahun 1955 dan $78 \%$ pada tahun 1991 (Nyak, C, 2008)

Dari survey awal yang dilakukan pada bulan februari 2015 di polindes putat kumpul pada 7 bayi, didapatkan 4 bayi yang memakai diapers dan mengalami ruam popok $(57,14 \%)$ karena kulit bayi yang menempel cukup lama dengan urine atau kotoran yang mengandung bahan ammonia, kulit terpapar bahan kimia atau terbuat dari plastik pada popok sekali pakai atau infeksi jamur, dan 3 bayi ( 42,86 $\%$ ) tidak mengalami ruam popok.

Menggunakan popok berdaya serap tinggi atau diapers pada bayi, harus lebih hati-hati, jika setiap saat bayi tidak lepas dari diapers akan berdampak negatif pada kondisi kulit bayi, pemakaian pampers secara terus-menerus akan mengurangi sensitivitas kulit bayi sehingga terjadi iritasi dan kulit bayi lebih tipis dan halus. Itu sebabnya kulit bayi lebih peka dan mudah terjadi gangguan kulit. Gangguan yang biasa timbul berupa ruam kulit yang dikenal dengan ruam popok (Soepardan, 2001:1)

Cara yang terbaik diapers digunakan maksimal 3 jam. Kenapa harus 3 jam sekali hal tersebut sesuai dengan jam minum bayi. Bayi minum maksimal tiap 3 jam sekali. Jadi biasakan sebelum memberikan minum, anda cek diapers anak anda. Basah atau tidak. Kalau tidak basah mungkin anda memberikan minumnya kurang. Sehingga bayi tidak BAK. Kenapa juga harus 3 jam 
sekali diganti karena air kencing mengandung asam laktat yang dapat menyebabkan iritasi. Mengganti diapers juga memberi rasa nyaman buat bayi, jadi untuk minum berikutnya bayi merasa senang dan akan minum banyak.(Gede Utomo, 2004).

\subsection{Identifikasi Masalah}

Faktor penyebab terjadinya ruam popok (diaper rash, diaper dermatitis, napkin dermatitis ), antara lain: Iritasi atau gesekan antara popok dengan kulit, faktor kelembaban, Kurangnya menjaga hygiene. popok jarang diganti atau terlalu lama tidak segera diganti setelah pipis atau BAB(feces), Infeksi mikro-organisme (terutama infeksi jamur dan bakteri), alergi bahan popok, gangguan pada kelenjar keringat di area yang tertutup popok, akibat daerah yang basah, ada luka atau sensitif terhadap bahan kimia tertentu, mengonsumsi makanan baru, penggunaan antibiotik.

\subsection{Rumusan Masalah}

Dari uraian latar belakang diatas maka dapat dirumuskan pertanyaan masalah sebagai berikut : Adakah hubungan pemakaian diapers dengan kejadian ruam popok pada bayi usia 6 bulan - 12 bulan di polindes putat kumpul, kecamatan turi, kabupaten lamongan tahun 2015?.

\subsection{Tujuan Penelitian}

Mengetahui hubungan antara pemakaian diapers dengan kejadian ruam popok pada bayi usia 6 bulan 12 bulan di polindes putat kumpul, kecamatan turi, kabupaten lamongan tahun 2015.

\subsection{Manfaat Penelitian}

Diharapkan penelitian ini mampu memberikan masukan profesi dalam mengembangkan perencanaan kebidanan yang akan melakukan penelitian tentang pemakaian pempers terhadap kesehatan kulit bayi.

$\begin{array}{llr}\text { Hasil penelitian ini dapat } \\ \text { menambah } & \text { wawasan, } & \text { ilmu } \\ \text { pengetahuan kesehatan dan dapat }\end{array}$ jadikan sebagai landasan penelitian berikutnya.

Hasil penelitian ini dapat memberikan informasi atau gambaran dalam mengetahui tentang pengetahuan ibu dalam pemakaian diapers terhadap kesehatan kulit bayi.

Dapat meningkatkan mutu pelayanan dalam menangani pasien dalam memberikan informasi tentang pemakaian diapers terhadap kesehatan kulit bayi yang dapat menyebabkan iritasi kulit.

Dapat menambah referensi khususnya bagi pembaca yang ingin mengadakan penelitian tentang hal yang sama.

\section{HASIL PENELITIAN}

Pada Bab ini mengungkapkan hasil penelitian yang berjudul "Hubungan Pemakaian diapers dengan Kejadian Ruam Popok Pada Kabupaten Lamongan" dengan jumlah sampel 30 orang.

Hasil penelitian ini disajikan dalam 2 bentuk yaitu data umum dan data khusus. Data umum berupa karakteristik responden berdasarkan umur ibu, pendidikan pekerjaan sedangkan data khusus yang disajikan berupa : pemakaian diapers, kejadian ruam popok, hubungan pemakaian diapers dengan kejadian ruam popok yang diprosentasekan dan 
diinterpretasikan sehingga dapat diketahui hasil dari penelitian yang telah dilakukan.

\subsection{Hasil Penelitian}

\subsubsection{Gambaran Lokasi Penelitian Polindes Putat Kumpul}

Data geografi :

1. Batas wilayah

Sebelah utara : Desa Jelak Catur

Sebelah selatan : Desa

Karangwedoro

Sebelah barat : Desa Pucang telu

Sebelah timur : Desa Kemlagilor

\subsubsection{Data Umum}

1. Umur ibu. Distribusi berdasarkan umur ibu bayi di Polindes Putat Kumpul, Kecamatan Turi Kabupaten Lamongan bulan Mei sampai Juli tahun 2015 disajikan sebagai berikut.

Table 2.1 Distribusi berdasarkan di Polindes Putat Kumpul, Kecamatan Turi Kabupaten Lamongan bulan Mei sampai Juli tahun 2015

\begin{tabular}{llcc}
\hline & $\begin{array}{c}\text { Umur } \\
\text { (Tahun) }\end{array}$ & $\mathrm{N}$ & $\begin{array}{c}\text { Prosentase } \\
(\%)\end{array}$ \\
\hline 1. & $>20$ & 3 & 10 \\
2. & Tahun & 22 & 73,33 \\
3. & $20-30$ & 5 & 16.67 \\
& Tahun & & \\
& $>30$ & & \\
& Tahun & & \\
\hline & Jumlah & 30 & 100 \\
\hline
\end{tabular}

Berdasarkan tabel 2.1 diatas dapat dilihat bahwa sebagian besar yakni $22(73,33 \%)$ ibu bayi berusia 20-30 tahun di Polindes Putat Kumpul, Kecamatan Turi Kabupaten Lamongan tahun 2015.

2. Pekerjaan Ibu Bayi

Distribusi berdasarkan pekerjaan ibu bayi di Polindes Putat Kumpul, Kecamatan Turi
Kabupaten Lamongan bulan Mei sampai Juli tahun 2015 disajikan sebagai berikut.

Tabel 2.2 Distribusi berdasarkan pekerjaan ibu bayi di Polindes Putat Kumpul, Kecamatan Turi Kabupaten Lamongan bulan Mei sampai Juli tahun 2015.

\begin{tabular}{|c|c|c|c|}
\hline No. & Pekerjaan & $\mathrm{N}$ & $\begin{array}{c}\text { Prosentase } \\
(\%)\end{array}$ \\
\hline 1. & IRT / & 18 & 60 \\
\hline 2. & Tidak & 7 & 23,33 \\
\hline \multirow[t]{4}{*}{3.} & bekerja & 5 & 16,67 \\
\hline & Swasta & & \\
\hline & PNS & & \\
\hline & Jumlah & 30 & 100 \\
\hline
\end{tabular}

Berdasarkan tabel 2.2 diatas dapat dilihat bahwa sebagian besar yakni $18(60 \%)$ ibu bayi pekerjaan IRT di Polindes Putat Kumpul, Kecamatan Turi Kabupaten Lamongan tahun 2015.

3. Pendidikan ibu bayi

Distribusi berdasarkan pendidikan ibu bayi di Polindes Putat Kumpul, Kecamatan Turi Kabupaten Lamongan bulan Mei sampai Juli tahun 2015 disajikan sebagai berikut.

Tabel 2.3 Distribusi berdasarkan pendidikan ibu bayi di Polindes Putat Kumpul, Kecamatan Turi Kabupaten Lamongan bulan Mei sampai Juli tahun 2015:

\begin{tabular}{llcc}
\hline No. & Pendidikan & N & $\begin{array}{c}\text { Prosentase } \\
(\%)\end{array}$ \\
\hline 1. & SMP & 3 & 10 \\
2. & SMA & 22 & 73,33 \\
3. & PT & 5 & 16,67 \\
\hline & Jumlah & 30 & 100 \\
\hline
\end{tabular}

Berdasarkan tabel 5.3 diatas dapat dilihat bahwa sebagian besar yakni $22 \quad(73,33 \%)$ ibu bayi 
pendidikan SMA di Polindes Putat Kumpul, Kecamatan Turi Kabupaten Lamongan tahun 2015.

\subsubsection{Data Khusus}

1. Pemakaian diapers

Distribusi

berdasarkan pemakaian diapers di Polindes Putat Kumpul, Kecamatan Turi Kabupaten Lamongan bulan Mei sampai Juli tahun 2015

Tabel 2.4 Distribusi berdasarkan pemakaian diapers di Polindes Putat Kumpul,

Kecamatan Turi

Kabupaten Lamongan bulan Mei sampai Juli tahun2015:

\begin{tabular}{llcc}
\hline No. & $\begin{array}{l}\text { Frekwensi } \\
\text { pemakaian }\end{array}$ & N & $\begin{array}{c}\text { Prosentase } \\
(\%)\end{array}$ \\
\hline 1. & Sering Pakai & 17 & 56,67 \\
2. & diapers & 10 & 33,33 \\
3. & Jarang Pakai & 3 & 10 \\
& diapers \\
& Tidak Pakai & & \\
& diapers & & \\
\hline & Jumlah & 30 & \\
& & 100 \\
\hline
\end{tabular}

Berdasarkan tabel 2.4 diatas dapat dilihat bahwa sebagian besar yaitu $17(56,67 \%)$ bayi sering pakai diapers di Polindes Putat Kumpul, Kecamatan Turi Kabupaten Lamongan tahun 2015.

2. Kejadian ruam popok

Distribusi berdasarkan kejadian ruam popok di Polindes Putat Kumpul, Kecamatan Turi Kabupaten Lamongan bulan Mei sampai Juli tahun 2015

Tabel 2.6 Distribusi berdasarkan kejadian ruam popok di Polindes Putat Kumpul, Kecamatan Turi Kabupaten Lamongan bulan Mei sampai Juli tahun 2015

\begin{tabular}{llcc}
\hline No. & Kejadian & N & $\begin{array}{c}\text { Prosentase } \\
(\%)\end{array}$ \\
\hline 1. & Ruam & 20 & 66,67 \\
2. & popok & 10 & 33,33 \\
& $\begin{array}{l}\text { Tidak ruam } \\
\text { popok }\end{array}$ & & \\
\hline & Jumlah & 30 & \\
& & & 100 \\
\hline
\end{tabular}

Berdasarkan tabel 2.4 diatas dapat dilihat bahwa sebagian besar yaitu $20(66,67 \%)$ bayi kejadian ruam popok di Polindes Putat Kumpul, Kecamatan Turi Kabupaten Lamongan tahun 2015.

Tabel Silang Hubungan Pemakaian Diapers dengan Kejadian Ruam Popok Pada Bayi Usia 6 bulan - 12 bulan di Polindes Putat Kumpul, Kecamatan Turi, Kabupaten Lamongan tahun 2015.

Tabel 2.6 Tabel Silang Hubungan Pemakaian Diapers dengan Kejadian Ruam Popok Pada Bayi Usia 6 bulan 12 bulan di Polindes Putat Kumpul, Kecamatan Turi, Kabupaten Lamongan tahun 2015.

\begin{tabular}{|c|r|r|r|}
\hline \multirow{2}{*}{$\begin{array}{c}\text { Pemakai } \\
\text { an } \\
\text { Diapers }\end{array}$} & \multicolumn{2}{|c|}{$\begin{array}{r}\text { Kejadian Ruam } \\
\text { Popok }\end{array}$} & \multirow{2}{*}{ Total } \\
\cline { 2 - 3 } & Popok & $\begin{array}{r}\text { Tidak } \\
\text { Ruam } \\
\text { Popok }\end{array}$ & \\
\hline $\begin{array}{c}\text { Sering } \\
\text { Pakai } \\
\text { Diapers }\end{array}$ & 15 & 2 & 17 \\
\hline $\begin{array}{c}\text { Jarang } \\
\text { Pakai }\end{array}$ & 58,24 & 11,76 & $100 \%$ \\
Diapers & $50 \%$ & $50 \%$ & $100 \%$ \\
\hline $\begin{array}{c}\text { Tidak } \\
\text { Pakai }\end{array}$ & 0 & 3 & 3 \\
Diapers & $0 \%$ & $100 \%$ & $100 \%$ \\
\hline Total & 20 & 10 & 30 \\
& $66,67 \%$ & $33,33 \%$ & $100 \%$ \\
\hline
\end{tabular}


Berdasarkan tabel 2.6 diatas dapat dijelaskan bahwa seluruhnya yaitu $17(100 \%)$ bayi yang pemakaian diapers, hampir seluruhnya yaitu $15(88,24 \%)$ bayi kejadian ruam popok yang sering pakai diapers dan sebagian kecil lagi yaitu 2 (11,76\%) bayi tidak kejadian ruam popok yang sering pakai diapers .

Dari hasil statistik koefisien kontingensi dan uji SPSS versi 16,0 dengan tingkat kemaknaan 0,05 didapatkan $\mathrm{C}=0,004 \mathrm{p}=0,000$, berarti $\alpha \geq \rho$, maka H0 ditolak artinya terdapat hubungan pemakaian diapers dengan kejadian ruam popok.

\subsection{PEMBAHASAN}

Pada bab ini dibahas tentang analisis data pemakaian diapers dengan kejadian ruam popok yang diperoleh dari penelitian yang dilaksanakan di Polindes Putat Kumpul, Kecamatan Turi, Kebupaten Lamongan tahun 2015.

\subsubsection{Pemakaian Diapers}

Dari tabel 2.4 didapatkan bahwa sebagian besar yaitu 17 $(56,67 \%)$ bayi sering pakai diapers, hampir setengahnya yaitu 10 $(33,33 \%)$ bayi jarang pakai diapers dan sebagian kecil lagi 3 (10\%) bayi tidak pakai diapers.

Pada bayi yang tidak terjadi ruam popok sebagian besar jarang dan tidak memakai diapers, hal ini disebabkan respon kulit terhadap agen - agen, misalnya zat kimia, protein, bakteri,dan fungus. Hampir semua bayi pernah mengalami ruam atau lecet karena pemakaian popok. Lokasi yang sering terkena adalah bagian pantat, sekitar kemaluan, maupun paha.Bahkan, jika bakteri yang terdapat dalam urine bayi Anda terurai menjadi amonia, ruam ini bisa bertambah parah. Tentu saja keadaan ini sangat tidak menyenangkan untuk bayi. Gejalanya antara lain ruam kemerahan atau lecet pada kulit di daerah yang ditutupi popok. Selain itu, bayi biasanya terlihat rewel, terutama saat penggantian popok. Bayi juga mungkin menangis saat kulit didaera hyang ditutupi popok dicuci atau disentuh.Terdapat bercak-bercak kemerahan pada daerah pantat karena iritasi popok. Sering-seringlah mengganti popok.

Jangan biarkan popok yang sudah basah karena menampung banyak urin berlama-lama dipakai bayi. Kontak yang lama antara urin atau tinja dengan kulit bayi dapat menimbulkan ruam popok. Saat membersihkan bayi, tepuk daerah yang biasa ditutupi popok (bokong, paha, selangkangan, dan daerah genital bayi) secara perlahan dengan handuk bersih. Usahakan menghindari menggosok-gosok dengan keras daerah tersebut.

Dengan begitu ibu mengetahui dampak yang akan terjadi jika ibu memakaikan diapers pada bayinya terlalu sering dan tidak diganti sedangkan popoknya sudah penuh, akan mengundang banyak kotoran atau mikroorganisme berkembang biak. Sehingga ibu lebih memperhatikan kondisi atau kenyamanan bayinya.

\subsubsection{Kejadian Ruam Popok}

Berdasarkan tabel 2.5 diatas dapat dilihat bahwa sebagian besar yaitu $20 \quad(66,67 \%)$ bayi kejadian ruam popok dan hampir setengahnya lagi yaitu $10(33,33 \%)$ bayi tidak ruam popok.

Hampir semua bayi pernah mengalami ruam atau lecet karena pemakaian popok.Lokasi yang sering terkena adalah bagian pantat, sekitar 
kemaluan, maupun paha.Bahkan, jika bakteri yang terdapat dalam urine bayi Anda terurai menjadi amonia, ruam ini bisa bertambah parah. Tentu saja keadaan ini sangat tidak menyenangkan untuk bayi. antara lain ruam popok kemerahan atau lecet pada kulit di daerah yang ditutupi popok. Selain itu, bayi biasanya terlihat rewel, terutama saat penggantian popok. Bayi juga mungkin menangis saat kulit didaera hyang ditutupi popok dicuci atau disentuh.Terdapat bercak-bercak kemerahan pada daerah pantat karena iritasi popok.

Sering-seringlah mengganti popok. Jangan biarkan popok yang sudah basah karena menampung banyak urin berlama-lama dipakai bayi. Kontak yang lama antara urin atau tinja dengan kulit bayi dapat menimbulkan ruam popok. Saat membersihkan bayi, tepuk daerah yang biasa ditutupi popok (bokong, paha, selangkangan, dan daerah genital bayi) secara perlahan dengan handuk bersih. Usahakan menghindari menggosok-gosok dengan keras daerah tersebut.

\subsubsection{Hubungan Pemakaian Diapers dengan Kejadian Ruam Popok}

Berdasarkan tabel 2.6 diatas dapat dijelaskan bahwa seluruhnya yaitu $17(100 \%)$ bayi yang pemakaian diapers, hampir seluruhnya yaitu $15(88,24 \%)$ bayi kejadian ruam popok yang sering pakai diapers dan sebagian kecil lagi yaitu $2(11,76 \%)$ bayi tidak kejadian ruam popok yang sering pakai diapers .

Dari hasil statistik koefisien kontingensi dan uji SPSS versi 16,0 dengan tingkat kemaknaan 0,05 didapatkan $\mathrm{C}=0,004 \mathrm{p}=0,000$, berarti $\alpha \geq \rho$, maka H0 ditolak artinya terdapat hubungan pemakaian diapers dengan kejadian ruam popok.

Diapers adalah salah satu produk seperti yang sebagian besar digunakan oleh orang tua baru karena tingkat kenyamanan mereka. Penggunaan luas dari popok plastik tinggi penyerap, namun menyebabkan beberapa kondisi kesehatan bayi baru lahir dan kulit sensitif mereka. ruam alergi, kemerahan, infeksi bakteri, demam, adalah beberapa kondisi yang disebabkan karena bahan kimia ini berdasarkan tinggi popok sekali pakai penyerap. Akibatnya, karena alasan-alasan yang paling tua baru dalam waktu hari ini lebih suka menggunakan organik kain popok untuk gelandangan lunak dan lembut bayi kecil mereka.

Disini dapat disimpulkan bahwa perlunya diberikan penyuluhan tentang pemakaian diapers yang terlalu sering bisa menimbulkan kejadian ruam popok agar ibu bisa menghindari pemakaian diapers yang teralul sering dan sering - sering mengganti diapers paling lama 3 jam sekali, kenapa harus 3 jam sekali hal tersebut sesuai dengan jam minum bayi. Bayi minum maksimal tiap 3 jam sekali. Jadi biasakan sebelum memberikan minum, anda cek pampres anak anda. Basah atau tidak. Kalau tidak basah mungkin anda memberikan minumnya kurang. Sehingga bayi tidak BAK. Kenapa juga harus 3 jam sekali diganti karena air kencing mengandung asam laktat yang dapat menyebabkan iritasi. Mengganti diapers juga memberi rasa nyaman buat bayi, jadi untuk minum berikutnya bayi merasa senang dan akan minum banyak. 


\subsection{Keterbatasan}

Keterbatasan

adalah

kelemahan atau keterlambatan dalam penelitian. Dalam hal ini peneliti akan melakukan seminimal mungkin disebabkan karena hal sebagai berikut :

- Peneliti baru pertama kali melakukan penelitian sehingga pengetahuan tentang penelitian masih kurang sehingga hasil kurang memuaskan.

- Sampel yang digunakan terbatas pada siswa yang memenuhi kriteria.

- Kuisoner dan lembar observasi sebagai alat pengumpulan data kurang valid, karena tidak dilakukan uji validitas dan reabilitas.

\section{KESIMPULAN}

\subsection{Kesimpulan}

Berdasarkan analisis data statistik dari 30 bayi di Polindes Putat Kumpul, Kecamatan Turi, Kabupaten Lamongan dapat diambil kesimpulan sebagai berikut :

1. Sebagian besar yaitu $17(56,67 \%)$ bayi pemakaian diapers yang sering pakai diapers di Polindes Putat Kumpul, Kecamatan Turi, Kabupaten Lamongan.

2. Sebagian besar yaitu 20 ( $66,67 \%$ ) bayi kejadian ruam popok yang ruam popok di Polindes Putat Kumpul, Kecamatan Turi, Kabupaten Lamongan.

3. Ada hubungan pemakaian diapers dengan kejadian ruam popok pada bayi usia 6 bulan - 12 bulan di Polindes Putat Kumpul, Kecamatan Turi, Kabupaten Lamongan.

\section{PUSTAKA}

Depkes RI ,1993. Asuhan kesehatan anak dalam konteks keluarga, Jakarta : PUSDIKNAKES Dep. Kes. RI

Diena, 2009. "Popok Modern bisa Sebabkan Mandul. Diakses pada tanggal 10 Juli 2015.

http//Dienaanakbunda.net/new/.

Lestari Y, dan Meryandini A. 2003. Identifikasi Bakteri Penghasil Mananase serta Karakterisasi Enzimnya. Jurnal Mikrobiologi Indonesia. Jurusan Biologi, FMIPA, Institut Pertanian Bogor.

Notoatmodjo S, 2005. Metodologi Penelitian Kesehatan. Jakarta : PT Asdi Mahasatya.

Soepardan, Suryani. 2001. Panduan Perawatan Bayi Sakit. Jakarta: Puspa Swara.

Yayasan Bina Pustaka Sarwono Prawirohadjo, 2007. Buku Acuan Nasional Pelayanan Kesehatan Maternal dan Neonatal. Jakarta : Tridasa Printer.

Arikunto, 2006. Metodologi Penelitian Kesehatan. Jakarta :EGC

Alimul Aziz. 2010. Metode Penelitian Kebidanan dan Teknik Analisis Data. Jakarta : Salemba Medika.

Yayasan Bina Pustaka Sarwono Prawirohadjo, 2007. Ilmu Kebidanan. Jakarta : Tridasa Printer.

Nursalam dan Siti Pariani. 2001. Metodologi Riset Perawatan. Jakarta : CV. Pioneer jaya. 